\title{
CIRCULAR SUPPLY CHAIN: LITERATURE REVIEW AND THEORETICAL FRAMEWORK
}

\author{
Tadas RADAVIČIUS ${ }^{*}{ }^{*}$, Manuela TVARONAVIČIENE் \\ Department of Business Technologies and Entrepreneurship, Faculty of Business Management, \\ Vilnius Gediminas Technical University, Sauletekio al. 11, LT-10223 Vilnius, Lithuania
}

Received 28 February 2021; accepted 01 April 2021

\begin{abstract}
Purpose - to review literature about circular supply chain (CSC) theories, methods, frameworks, and applications in industries. For organizations to incorporate circular economy (CE) principles in their supply chain framework are required to address the main circular processes. Previous attempts of frameworks aim at the comprehensive approaches or too theoretical for organizations to use them. The objective is to propose a theoretical framework that allows organizations to prioritize main circular processes in order to start improving or introducing new circular processes in the supply chain.

Research methodology - the methodology of the article consists of a literature review and information synthesis for the formulation of the theoretical framework. Web of Science database was used for literature review with the key words of "circular economy supply chain".

Findings - formulated theoretical CSC framework contributes to the CSC research field with a more organization-orientated approach.

Research limitations - the proposed framework is limited through only theoretical propositions and is more limited in its scope compared to other researchers.

Practical implications - organizations in the supply chain such as manufacturers can understand through a framework main processes required for CSC.

Originality/Value - compared to other researchers this work emphasizes and proposes CSC development from an organizational perspective rather than from a holistic approach.
\end{abstract}

Keywords: circular supply chain, theoretical framework, circular economy, literature review, closed-loop system, digitalisation.

JEL Classification: L23.

Conference topic: Business Processes: Development, Digitalisation, Social Responsibility.

\section{Introduction}

Climate change and resource scarcity are challenging organizations capability to continue operating in the long term. Circular economy theories provide insights and understanding that transformations are needed in the supply chains to keep materials in closed-loop systems in order to minimize waste and ensure ever-lasting access to the materials. The need for creating circular supply chains in various industries are being investigated by researchers and organizations (Mazzoni, 2020; Makarova et al., 2021; Ouhimmou et al., 2021). The paper discusses different approaches suggested by authors to achieve CSC.

The objective of the research is to review CSC literature and synthesize the information to develop a theoretical CSC framework. Web of Science database was used to search relevant articles towards CSC with keywords of "circular economy supply chain".

Research is aimed to review the literature of circular supply chain theories, theoretical frameworks, methods and attempts to apply them in different industries. Various challenges, drivers, and barriers of CSC are discussed in the paper. The purpose is to define a theoretical framework that would be used for organizations to understand the main processes of CSC.

*E-mail: tadas.radavicius@vilniustech.lt

(C) 2021 Authors. Published by Vilnius Gediminas Technical University. This is an open-access article distributed under the terms of the Creative Commons Attribution (http://creativecommons.org/licenses/by/4.0/) License, which permits unrestricted use, distribution, and reproduction in any medium, provided the original author and source are credited. 
The article reviews different researchers' approaches towards circular supply chains. With the increased attention of organizations role in achieving more sustainable production \& consumption CE allows grasping opportunities of new business strategies through the implementation of CSC's. With raw materials limitations organizations can contribute towards secondary materials, components, and products (MCP) stock. This goal requires organizations develop and introduce new circular supply chain processes such as prolonging product life by repairing, reusing, etc. As there are various barriers and challenges for organizations to develop these processes different authors propose various methods of how CSC processes can be achieved.

The evident problem of CSC in the research field is focusing on comprehensive factors and elements affecting the system. As this is a rather new research field there is a lack of development towards theoretical frameworks which could lead towards the development of tools and methods for organizations (suppliers, manufacturers, etc.) to take initiative for improving supply chain circularity.

\section{Literature review}

Batista, Bourlakis, Smart, and Maull (2018) based on the literature review of different circular supply chain definitions such as closed-loop supply chain, sustainable supply chain management, green supply chains, and reverse suggest the following description of the circular supply chain:

"The coordinated forward and reverse supply chain via purposeful business ecosystem integration for value creation from products/services, by products and useful waste flows through prolonged life cycles that improve the economic, social and environmental sustainability of organizations" (Batista et al., 2018).

A circular supply chain involves the reduction of raw materials by providing substitutes that are long-lasting, upgradable, made with renewable energy sources (RES), recyclable, and upcyclable (Maranesi \& De Giovanni, 2020). Upcycle of materials means that the materials should not lose their quality after the recycling processes. Whereas Maranesi and Giovanni (2020) were not against low-value recycling (down-cycle) Kopnina (2018) argues that based on the cradle-to-cradle approach downcycle should be avoided. Authors view on the circular supply chain is heavily impacted on the theories related to the circular economy supply chain. Ogunmakinde, Sher, and Egbelakin (2021) identified main theories, concepts, and methods that affect the circular supply chain: industrial ecology, cradle to cradle, regenerative design, natural capitalism, biomimicry, blue economy, eco-efficiency, eco-effectiveness, reverse logistics, zero emissions, performance economy, permaculture, extended producer responsibility, and material passport. The core connection is that all the topics are related to environmental protection. A closed-system supply chain where materials are constantly returned to industries supply is the core of the circular supply chain (Cannella et al., 2021). It is a difficult goal to achieve in the current world where dominant end-of-life (EoL) treatment of MCP's leads to loss of materials and their quality (Singh et al., 2019). The transition from business-as-usual (BAU) supply chain towards circular supply chain requires shift of organizations strategies, structures, MCP's flows, and collaboration practices between the supply chain "actors" (De Angelis et al., 2018). These processes are complex and require close co-operation of supply chain "actors" to introduce circular processes.

Various authors attempted to identify barriers, drivers, practices, and challenges of the circular supply chain (Acerbi \& Taisch, 2020; Bressanelli et al., 2019; Govindan \& Hasanagic, 2018; Iacovidou et al., 2020; Khan \& Haleem, 2021; Kumar et al., 2021). Table 1 shows the summarized structure of the circular supply chain key focus areas through challenges, drivers, and barriers.

Information sharing difficulty can be solved by technologies such as RFID's, 3d scanning lasers, optical character recognition, building information modeling, sensors networks, blockchain, etc. (Iacovidou et al., 2020). Data management enabled by digital technologies allows optimizing CSC solutions and processes (Del Giudice et al., 2020). The careless behavior of users can be resolved by enabling product-service systems where ownership of the product is kept by the company (Geissdoerfer et al., 2020). The higher stock of secondary materials can reduce the unpredictability of the market (Eurostat, 2017). With lower uncertainty of secondary materials price, the demand for these materials would possibly increase. Therefore, it would create demand for new scalable high-value recycling processes as the current market demands different materials quality (Iacovidou et al., 2020). The designing of MCP's and business as usual (BAU) logistics adaption for CSC requires co-operation between the supply chain organizations. Even if the processes are created to ensure circularity and therefore introduce repairable, reusable, etc. products it's still a challenge for organizations to develop successful circular business models. Khan and Haleem demonstrated that organizations have a wide range of practices towards solving one or another challenge related to CSC such as developing a circular culture in the organization, environmental criteria for supplier selection, etc. (Khan \& Haleem, 2021).

For organizations to prioritize focus on specific areas of CSC researchers proposed different ways how to rank or categorize CSC processes related to MCPs. Cole, Gnanapragasam, Cooper, and Singh (2019) attempted to define and rank layers of designing levels and hierarchy:

- Reduce and conserve materials, design out waste, reduce consumption, longer-lasting products (highest ranking). 
Table 1. Circular supply chain challenges, barriers, and drivers (source: adapted from Acerbi \& Taisch, 2020; Bressanelli et al., 2019; Govindan \& Hasanagic, 2018; Iacovidou et al., 2020; Khan \& Haleem, 2021; Kumar et al., 2021)

\begin{tabular}{|c|c|c|}
\hline Challenges & Barriers & Drivers \\
\hline $\begin{array}{l}\text { Information sharing between the } \\
\text { supply chain actors }\end{array}$ & $\begin{array}{l}\text { Low incentive, minimum awareness of } \\
\text { industry } 4.0 \text {, and lack of importance } \\
\text { understanding for sharing MCP's related } \\
\text { information which is required to achieve } \\
\text { CSC processes }\end{array}$ & $\begin{array}{l}\text { Boost operation efficiency of } \\
\text { organizations and allow new business } \\
\text { processes for repairing, high-value } \\
\text { recycling, etc. }\end{array}$ \\
\hline Careless behavior in product usage & Lack of public awareness & $\begin{array}{l}\text { Rise of green product awareness and } \\
\text { growth of service-based products models }\end{array}$ \\
\hline $\begin{array}{l}\text { Entry barriers and low market } \\
\text { incentives for repaired, refurbished, } \\
\text { second-hand products, etc. }\end{array}$ & $\begin{array}{l}\text { Lack of market regulations and lack of } \\
\text { incentives for circular products }\end{array}$ & $\begin{array}{l}\text { Reduce environmental impact by } \\
\text { prolonging effectively MCP's life }\end{array}$ \\
\hline $\begin{array}{l}\text { Underdeveloped technologies for } \\
\text { end-of-life MCP's treatment }\end{array}$ & $\begin{array}{l}\text { The high financial investment required to } \\
\text { R\&D and lack of co-operation between } \\
\text { supply chain actors to develop new processes }\end{array}$ & $\begin{array}{l}\text { Increase the value of the product and } \\
\text { new business activities for national and } \\
\text { local companies }\end{array}$ \\
\hline Scale EoL processes & $\begin{array}{l}\text { Lack of standards, regulation, and policy } \\
\text { supports aimed at high-value recycling and } \\
\text { other circular EoL processes }\end{array}$ & $\begin{array}{l}\text { Reducing environmental impact and } \\
\text { boosting national and regional secondary } \\
\text { material stocks }\end{array}$ \\
\hline Designing MCP's in a circular way & $\begin{array}{l}\text { Lack of co-operation between supply chain } \\
\text { actors }\end{array}$ & $\begin{array}{l}\text { MCP's with a longer lifetime, less toxic } \\
\text { and more repairable, recyclable, etc. }\end{array}$ \\
\hline Logistics to support CSC & $\begin{array}{l}\text { Additional costs for reverse logistics } \\
\text { introduction }\end{array}$ & $\begin{array}{l}\text { New revenue streams for the } \\
\text { organizations to repair, refurbish, re-use, } \\
\text { etc., MCP's }\end{array}$ \\
\hline
\end{tabular}

- Encourage cyclical use of resources and develop incentives to reduce waste.

- Design products for sustainability and take-back.

- Reuse.

- Recycle.

- Regulate disposal (lowest ranking).

The main focus is the designing phases of MCP's which done effectively can significantly reduce difficulties related to reuse, recycle and disposal. Varbanov, Jia, and Lim (2021) proposed 4 main processes for handling EoL MCP's:

- Waste separation.

- Material recovery and recycling.

- Waste-to-Energy.

- Landfill.

The enabling condition for these 4 processes to flourish (except the landfill process) is logistics as Varbanov et al. (2021) suggest. Logistics are related to the transportation of MCP's between various supply chain "actors" such as manufacturer, repairer, user, etc. A new classification of waste is required to adopt CE principles for organizations and countries to account for reused products, higher recycling rates, quality standards for secondary raw materials, etc. (Nikanorova \& Stankevičienè, 2020). The need to improve logistics for CSC reverse logistics in terms of tracking, information accessibility, and management of data is evident due to various conditions of products and their geographical distribution (De Angelis et al., 2018). Reverse logistic category processes involve repair, refurbishment, disassembly, servicing, remanufacturing, recycling, and disposal (Kruczek \& Zawartka, 2019). In addition to circular supply chain processes of collection, maintenance, and reuse CSC enables new business models such as sharing platforms and product as a service models (Kruczek \& Zawartka, 2019).

Researchers had different approaches to conceptualizing the systems and/or their processes of the circular supply chain. Iacovidou et al. (2020) proposed that CSC is a combination of multiple systems: internal sub-system (processes, actions, values) and external systems (technologies, governance, natural resources, etc.) forming a system of systems. Iacovidou et al. (2020) theoretical system allows to identify and understand required changes towards sustainable transition. It is a well-elaborated and defined system that takes into account cultural and user behavior influence, policies, values (economical, environmental, etc.), business and market activities, technology, innovations, etc. Awan, Sroufe, and Shahbaz (2021) investigated stakeholders (international organizations, institutions, suppliers) view related to the interest of concerns, expectations, and strategies towards CSC. The findings show that there is a high interconnection between the organizations towards the success of any supply chain "actor" strategy or objectives fulfillment. It demonstrates the crucial requirements of co-operation between the CSC "actors" for achieving goals that have a positive impact on multiple supply chain organizations and the users. Geissdoerfer, Morioka, Carvalho, and Evans (2018) in their framework of circular supply chain incorporates circular business models which derive from the organizational level. Geissdoerfer, Pieroni, Pigosso, and Soufani (2020) also showcase that the circular sup- 
ply chain is the interconnection field between sustainable development and circular economy. Vegter, Hillegersberg, and Olthaar (2020) demonstrated CSC and CBM from a processes perspective by proposing two levels of processes. Vegter et al. (2020) suggested first-level processes composition of a plan, source, make, deliver, use, return, recover, enable. The second level processes consist of more concrete processes, such as plan the supply chain, deliver stocked products, return defective products, etc. The proposed system of CSC and CBM demonstrates high-level responsibility for organizations to organize and maintain mentioned processes.

The circular economy practical framework standard (BS 8001:2017) for organizations was created in 2017 by British standards institution (Pauliuk, 2018). Its purpose is to allow any kind of organization (any sector, size, type) to take responsibility for implementing more circular organization processes. The standard has concrete suggestions for organizations supported by a comprehensive approach but lacks monitoring and measurement of the CSC solutions and development of business models (Pauliuk, 2018). Pauliuk (2018) proposed his own indicators list to measure processes circularity related to measuring recyclability, restored materials, quality of materials, etc. Nikanorova and Stankevičienė (2020) proposed different approach towards the indicator system of circularity consisting of the following groups: waste management, air pollution and $\mathrm{CO} 2$ emissions, energy, economic opportunities and policy responses, material management, and economic context. The indicators are circular material use rate, trade-in recyclable raw materials, the recycling rate of municipal waste, etc. These indicators are more focused to evaluate the circularity at the country level, but due to their formulation which derives from 10R (refuse, rethink, reduce, etc.), they could be adapted at the organization level as well. To understand better CSC further research investigations are suggested to explore topics such as design for circularity, procurement and CSC, circular supply chain collaboration and coordination, circular consumption, product liabilities and producer's responsibility, and CSC enabling technologies (Farooque et al., 2019).

Researchers attempted to apply CSC theories and methods to different industries. Table 2 shows 4 different industries and the researchers attempts to improve the circularity of the industry supply chain. Optimization is an important factor that can allow economically attractive CSC processes. The case study of truck manufacturer demonstrated that economic benefits can be achieved by having EoL circular process - repairing. Other researchers show that mathematical models approach and scenario-modeling is an attractive tool for researchers to showcase the theoretical impact of different CSC solutions.

The literature review demonstrates various practices, methods, and approaches to how organizations are capable to take responsibility for supply chain improvement towards circularity. Theoretical approaches allow organizations to have a broader understanding of the interconnection of each "actor" in the supply chain to overcome challenges for CSC development. To allow organizations to take action in developing their CSC current theoretical frameworks are either too broad and theoretical for business people.

Table 2. Researches related to improving CSC processes (source: created by the authors)

\begin{tabular}{|c|c|c|c|c|}
\hline Industry & Research object & CSC method applied & Results & Researchers \\
\hline Paper & $\begin{array}{l}\text { Case study of the } \\
\text { paper manufacturing } \\
\text { company }\end{array}$ & $\begin{array}{l}\text { Digitalization solution to } \\
\text { gather information }\end{array}$ & $\begin{array}{l}\text { Unlocked critical decision making } \\
\text { which allowed to improve operational } \\
\text { efficiency }\end{array}$ & $\begin{array}{l}\text { (Manavalan \& } \\
\text { Jayakrishna, } \\
\text { 2019) }\end{array}$ \\
\hline Forest & Forest value chain & $\begin{array}{l}\text { Circular bioprocesses } \\
\text { and their output products } \\
\text { commercialization } \\
\text { demonstration through a } \\
\text { mathematical model }\end{array}$ & $\begin{array}{l}\text { Inputs received by various forest value } \\
\text { chain organizations showcased through } \\
\text { a mathematical model that for circular } \\
\text { processes and their products economical } \\
\text { feasibility scalability of the processes is } \\
\text { crucial }\end{array}$ & $\begin{array}{l}\text { (Ouhimmou } \\
\text { et al., 2021) }\end{array}$ \\
\hline Construction & $\begin{array}{l}\text { Construction } \\
\text { waste processing } \\
\text { organizations }\end{array}$ & $\begin{array}{l}\text { Networking theoretical } \\
\text { architecture of reverse } \\
\text { logistics was created } \\
\text { to formulate scenarios } \\
\text { based on the intensity of } \\
\text { materials recovery through a } \\
\text { mathematical model }\end{array}$ & $\begin{array}{l}\text { The most optimal scenario showcases a } \\
24 \% \text { reduction in the cost of handling } \\
\text { construction waste which includes } \\
\text { a higher percentage of waste being } \\
\text { recycled compared to the base case }\end{array}$ & $\begin{array}{l}\text { (Ahmed \& } \\
\text { Zhang, 2021) }\end{array}$ \\
\hline Automobile & Truck manufacturer & $\begin{array}{l}\text { Process optimization for } \\
\text { spare-parts delivery }\end{array}$ & $\begin{array}{l}\text { Results based on modeled scenarios } \\
\text { shows economic benefits for a company } \\
\text { to operate services for repairing trucks } \\
\text { by providing spare-parts }\end{array}$ & $\begin{array}{l}\text { (Makarova } \\
\text { et al., 2021) }\end{array}$ \\
\hline
\end{tabular}




\section{Proposed theoretical framework}

For organizations to focus on the main processes of CSC and investigate the potential and feasibility of CSC solutions a theoretical framework is proposed based on a literature review. Figure 1 "Circular supply chain theoretical framework" demonstrates sub-system and system interconnection with each other and the environmental factors affecting the whole system. Sub-system consists of information sharing, MCP's circular design, logistics, and circular product EoL processes:

- MCP's circular design: discussions and co-operation about the possible design changes of MCP's to allow repairability, recyclability, etc. needs to be addressed by all supply chain "actors". This is the main process where circularity can be introduced. The impact of designing MCP's will be felt in all other processes.

- Information sharing: processes related to agreeing on the required information about MCPs between the "actors", such as in-depth material passport, using digital technologies to allow product traceability, platforms for data storage and management, etc. As discussed in literature the importance of understanding every "actor" needs in terms of specific MCP information and its traceability is an important step to allow a more circular supply chain.

- Circular product end-of-life processes: these processes are related to repairing, recycling, re-use, refurbishment, etc. All processes that are happening after the product is for some reason returned by the user (defects, not required anymore, broken, etc.).

- Logistics: related with MCP's transportation through the supply chain and at the end-of-life phase. Digital technologies introduction and optimized logistics can allow to reduce costs and enable various business models related to end-of-life processes.

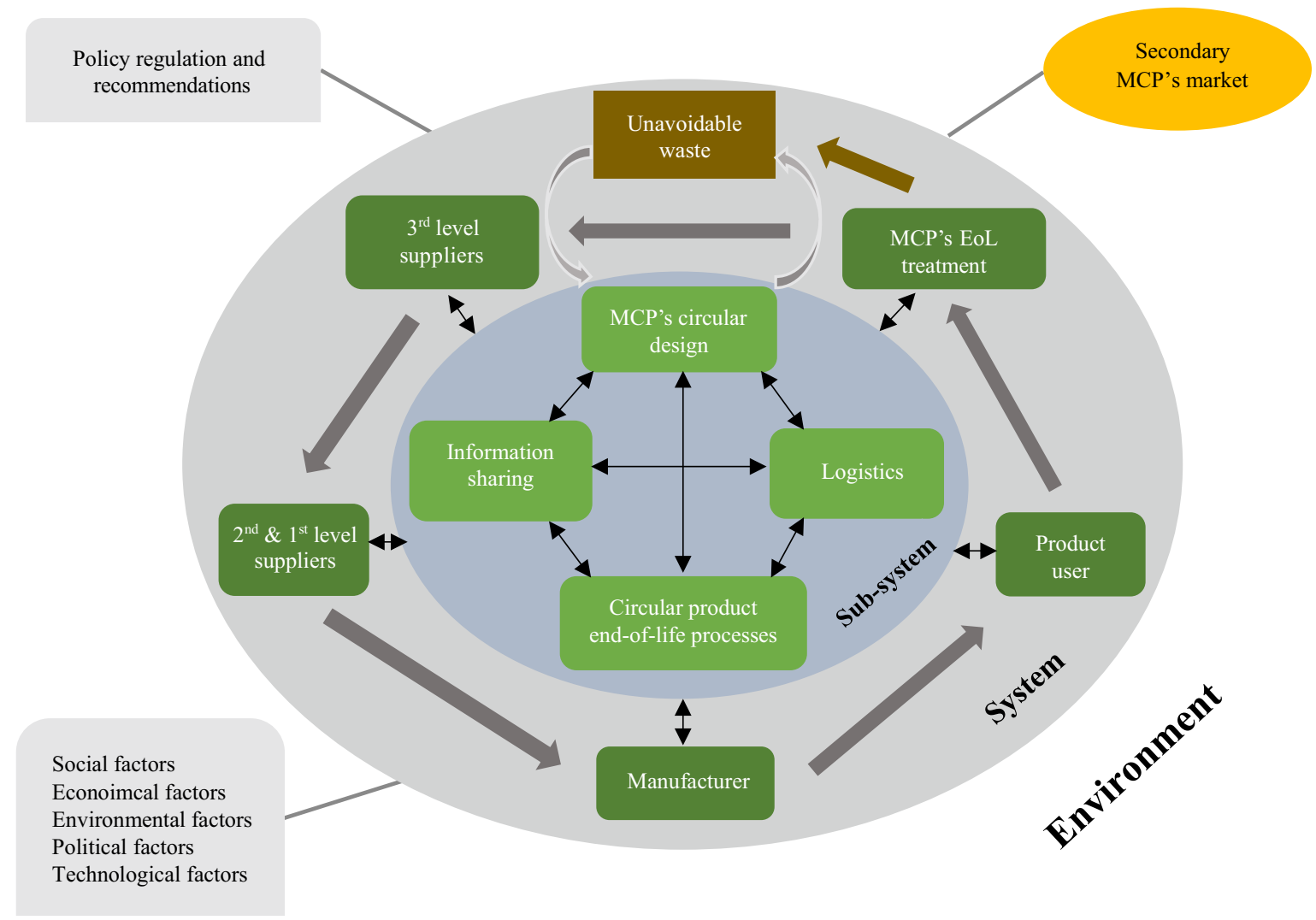

Figure 1. Circular supply chain theoretical framework (source: created by the authors)

Each of the sub-system elements are interconnected with each other. MCP's design depends on how it will be transported, how digital information (barcode, RFID tag, etc.) can be identified in the MCP's and how and who will be participating in end-of-life processes. Each of the elements requires either inputs or outputs in terms of recommendations, MCP's changes, information required to develop processes, etc., from each other.

The upper system includes $1^{s t}, 2^{\text {nd }}$, and $3^{\text {rd }}$ level suppliers, manufacturer, product user, and MCP's EoL treatment which is done by organizations related to recycling, repairing, etc. Each of the CSC "actors" are linked to a sub-system where the supply chain actors are involved in the development, supporting, and maintaining circular processes. These supply chain actors have a sturdy circular connection from the perspective of materials flow which is transformed to the component, product, EoL products, etc.: 
- $3^{\text {rd }}$ level suppliers. The third level suppliers are those who process raw materials for them to be used for components production or further development by other suppliers to produce parts.

$-2^{\text {nd }} \& 1^{\text {st }}$ level suppliers. These suppliers manufacturers components or parts from the materials provided by $3^{\text {rd }}$ level suppliers.

- Manufacturers. Product manufacturer or system assembler. Usually, this is the organization that has extensive knowledge about the supply chain and is capable to initiate dialogue with other supply chain "actors" in order to investigate the feasibility of circular supply chain processes.

- Product user. Is the product user which in some cases are linked to the organization which offers servitization of the product. Servitization is understood as an organization keeping product ownership and providing the product (product outcome/output) as a service.

- MCP's EoL treatment. These are organizations related to recycling, collection, repairing, etc., activities. EoL treatment activities can be understood as further MCP's life after the first use which was discontinued due to defect, expiration, etc. Unavoidable waste is the by-product of EoL treatment which adds no value (economical, environmental) if it re-enters the same or other supply chain flows due to current technological limitations for materials recovery and purification, toxicity, etc. Unavoidable waste should be one of the focus areas for circular processes to create more circular MCP's to minimize waste.

These supply chain actors are the main shareholders or stakeholders that organization needs to incorporate for the development of a circular supply chain. Sub-system and the system affected by economical, political, social, environmental, and technological factors. The feasibility for organizations to take action for developing CSC is often limited by one or all factors. It is important to understand the environment of a specific industry to explore methods that would allow improving circularity in the supply chain. The other 2 key environmental elements are:

- Policy regulation and recommendations. They are directly impacting the capability of the organization to develop processes for CSC. Policy regulations impact heavily the scalability of circularity processes such as second-hand products where the product once stated as a waste return to the market. The recommendations are either from institutes, academia, other organizations practices, etc., which suggests how the CSC should be constructed. It allows supply chain actors to look for adaptable solutions and ensure that their solution meets not only CSC criteria but also sustainability factors (social, safety, etc.).

- Secondary MCP's market. To have circular sub-system processes such as MCP's circular design information and analysis is required to understand in which industries recovered materials from EoL product could be used. The components and products secondary market potential allows to have critical decision making whether the second-hand products and/or components would have market demand and if processes could be scaled to meet the demand of secondary MCP's.

The overall theoretical framework is constructed in a way to highlight the interconnection of each supply chain actor's relevance towards the creation of a circular supply chain. Co-operation is required between the supply chain "actors". It can be achieved by one of the supply chain organization initiatives to review current supply chain status and investigate circular processes feasibility to create improved MCP's and to develop new business models based on circular processes.

\section{Limitations}

The framework is limited in its scope compared to other theoretical frameworks presented in the literature review. Methods on how to organize and manage CSC "actors" to develop circular processes are not proposed. The reference list and sources in this article's theoretical research development were lower than in other papers. Due to the synthesis of literature review and lack of direct connection between the literature review and argumentations of proposed theoretical framework systems, elements and factors the framework is less viable and understandable from a scientific perspective compared with other works in the CSC research field.

\section{Conclusions}

The research paper proposed a theoretical model for a circular supply chain. The literature review showed that researchers are trying to investigate and apply various theories and methods towards CSC. Hierarchy ranking of processes shows the evident importance of focusing on designing MCP's. To achieve it it is important to understand the interest of concerns of all value chai factors for successful collaboration. Challenges and barriers for SCS implementation derive from various areas such as market, policies, technological issues, and so on. To overcome them researchers proposed various methods such as design for circularity, suppliers selection based on environmental criteria, etc. Researchers attempt to find CSC solutions in different industries showed that economically attractive circular processes are achievable. It also demonstrated that CSC solutions scenario modeling is the method that can allow without a big investment to understand the economical attractiveness of the solutions. 
The proposed theoretical framework highlights the relevant factors and processes for organizations. It is a less comprehensive system compared to the existing theoretical frameworks in the literature. It is developed from organizations perspectives in order for the organizations which take the responsibility for CSC development to focus on the main processes. The novelty of work is the proposed theoretical framework with the focus on the industry level for practitioners and organizations to understand the main processes of circular supply chain.

The limitations of the study consist of using only one database: Web of Science. The keywords were also limited only to "circular economy supply chain". Compared with other researches in the field of CSC, the literature review is weaker in terms of the diversity and amount of analyzed studies.

Further research could attempt to apply the framework to a specific industry to define or adapt suitable methods from literature to achieve supply chain "actors" co-operation (workshops, discussions, experiments, etc.) and tailored specific CSC solutions \& processes for the industry.

\section{Disclosure statement}

We declare that we do not have any competing financial, professional, or personal interests from other parties.

\section{References}

Acerbi, F., \& Taisch, M. (2020). A literature review on circular economy adoption in the manufacturing sector. In Journal of Cleaner Production, 273, 123086. https://doi.org/10.1016/j.jclepro.2020.123086

Ahmed, R. R., \& Zhang, X. (2021). Multi-stage network-based two-type cost minimization for the reverse logistics management of inert construction waste. Waste Management, 120, 805-819. https://doi.org/10.1016/j.wasman.2020.11.004

Awan, U., Sroufe, R., \& Shahbaz, M. (2021). Industry 4.0 and the circular economy: A literature review and recommendations for future research. Business Strategy and the Environment, 2021, 1-23. https://doi.org/10.1002/bse.2731

Batista, L., Bourlakis, M., Smart, P., \& Maull, R. (2018). In search of a circular supply chain archetype - a content-analysis-based literature review. Production Planning \& Control, 29(6), 438-451. https://doi.org/10.1080/09537287.2017.1343502

Bressanelli, G., Perona, M., \& Saccani, N. (2019). Challenges in supply chain redesign for the Circular Economy: A literature review and a multiple case study. International Journal of Production Research, 57(23), 7395-7422. https://doi.org/10.1080/00207543.2018.1542176

Cannella, S., Ponte, B., Dominguez, R., \& Framinan, J. M. (2021). Proportional order-up-to policies for closed-loop supply chains: The dynamic effects of inventory controllers. International Journal of Production Research. https://doi.org/10.1080/00207543.2020.1867924

Cole, C., Gnanapragasam, A., Cooper, T., \& Singh, J. (2019). An assessment of achievements of the WEEE Directive in promoting movement up the waste hierarchy: experiences in the UK. Waste Management, 87, 417-427. https://doi.org/10.1016/j.wasman.2019.01.046

De Angelis, R., Howard, M., \& Miemczyk, J. (2018). Supply chain management and the circular economy: Towards the circular supply chain. Production Planning \& Control, 29(6), 425-437. https://doi.org/10.1080/09537287.2018.1449244

Del Giudice, M., Chierici, R., Mazzucchelli, A., \& Fiano, F. (2020). Supply chain management in the era of circular economy: The moderating effect of big data. International Journal of Logistics Management, (ahead-of-print). https://doi.org/10.1108/IJLM-03-2020-0119

Eurostat. (2017). Recycling - secondary material price indicator. Statistics Explained. https://ec.europa.eu/eurostat/statistics-explained/index.php/Recycling___secondary_material_price_indicator\#Price_and_trade_volumes

Farooque, M., Zhang, A., Thürer, M., Qu, T., \& Huisingh, D. (2019). Circular supply chain management: A definition and structured literature review. Journal of Cleaner Production, 228, 882-900. https://doi.org/10.1016/j.jclepro.2019.04.303

Geissdoerfer, M., Morioka, S. N., de Carvalho, M. M., \& Evans, S. (2018). Business models and supply chains for the circular economy. Journal of Cleaner Production, 190, 712-721. https://doi.org/10.1016/j.jclepro.2018.04.159

Geissdoerfer, M., Pieroni, M. P. P., Pigosso, D. C. A., \& Soufani, K. (2020). Circular business models: A review. Journal of Cleaner Production, 277, 123741. https://doi.org/10.1016/j.jclepro.2020.123741

Govindan, K., \& Hasanagic, M. (2018). A systematic review on drivers, barriers, and practices towards circular economy: A supply chain perspective. International Journal of Production Research, 56(1-2), 278-311. https://doi.org/10.1080/00207543.2017.1402141

Iacovidou, E., Hahladakis, J. N., \& Purnell, P. (2020). A systems thinking approach to understanding the challenges of achieving the circular economy. Environmental Science and Pollution Research, 1-22. https://doi.org/10.1007/s11356-020-11725-9

Khan, S., \& Haleem, A. (2021). Investigation of circular economy practices in the context of emerging economies: A CoCoSo approach. International Journal of Sustainable Engineering, 1-11. https://doi.org/10.1080/19397038.2020.1871442

Kopnina, H. (2018). Circular economy and Cradle to Cradle in educational practice. Journal of Integrative Environmental Sciences, 15(1), 119-134. https://doi.org/10.1080/1943815x.2018.1471724

Kruczek, M., \& Zawartka, P. (2019). The importance of the circular economy for reverse logistics systems improvement. In $8^{\text {th }}$ Carpathian Logistics Congress (CLC 2018) (pp. 592-597). Prague, Czech Republic. https://www.confer.cz/clc/2018/2465-the-importance-of-the-circular-economy-for-reverse-logistics-systems-improvement 
Kumar, P., Singh, R. K., \& Kumar, V. (2021). Managing supply chains for sustainable operations in the era of industry 4.0 and circular economy: Analysis of barriers. Resources, Conservation and Recycling, 164, 105215. https://doi.org/10.1016/j.resconrec.2020.105215

Makarova, I., Shubenkova, K., Buyvol, P., Shepelev, V., \& Gritsenko, A. (2021). The role of reverse logistics in the transition to a circular economy: Case study of automotive spare parts logistics. FME Transactions, 49(1), 173-185. https://doi.org/10.5937/fme2101173M

Manavalan, E., \& Jayakrishna, K. (2019). An analysis on sustainable supply chain for circular economy. Procedia Manufacturing, 33, 477-484. https://doi.org/10.1016/j.promfg.2019.04.059

Maranesi, C., \& De Giovanni, P. (2020). Modern circular economy: Corporate strategy, supply chain, and industrial symbiosis. Sustainability, 12(22), 9383. https://doi.org/10.3390/su12229383

Mazzoni, F. (2020). Insights into regional development circular economy and eco-innovation in Italian industrial clusers best practices from Prato textile cluster. Insights into Regional Development, 2(3), 661-676. https://doi.org/10.9770/IRD.2020.2.3(4)

Nikanorova, M., \& Stankevičienè, J. (2020). Entrepreneurship and sustainability issues development of environmental pillar in the context of circular economy assessment: Baltic Sea Region case. Entrepreneurship and Sustainability Issues, 8(1), 1209-1223. https://doi.org/10.9770/jesi.2020.8.1(81)

Ogunmakinde, O. E., Sher, W., \& Egbelakin, T. (2021). Circular economy pillars: A semi-systematic review. Clean Technologies and Environmental Policy, 23, 899-914. https://doi.org/10.1007/s10098-020-02012-9

Ouhimmou, M., Rönnqvist, M., \& Lapointe, L. A. (2021). Assessment of sustainable integration of new products into value chain through a generic decision support model: An application to the forest value chain. Omega, 99, 102173. https://doi.org/10.1016/j.omega.2019.102173

Pauliuk, S. (2018). Critical appraisal of the circular economy standard BS 8001:2017 and a dashboard of quantitative system indicators for its implementation in organizations. Resources, Conservation and Recycling, 129, 81-92. https://doi.org/10.1016/j.resconrec.2017.10.019

Singh, J., Sung, K., Cooper, T., West, K., \& Mont, O. (2019). Challenges and opportunities for scaling up upcycling businesses The case of textile and wood upcycling businesses in the UK. Resources, Conservation and Recycling, 150, 104439. https://doi.org/10.1016/j.resconrec.2019.104439

Varbanov, P. S., Jia, X., \& Lim, J. S. (2021). Process assessment, integration and optimisation: The path towards cleaner production. Journal of Cleaner Production, 281, 124602. https://doi.org/10.1016/j.jclepro.2020.124602

Vegter, D., van Hillegersberg, J., \& Olthaar, M. (2020). Supply chains in circular business models: processes and performance objectives. Resources, Conservation and Recycling, 162, 105046. https://doi.org/10.1016/j.resconrec.2020.105046 